\title{
Soil Carbon Sequestration in Traditional Farming in Sudanese Dry Lands
}

\author{
JONAS ARDÖ* \\ Department of Physical Geography and Ecosystems Analysis \\ Lund University \\ Sölvegatan 12, S-223 62 Lund, Sweden

\section{LENNART OLSSON} \\ Centre for Environmental Studies \\ Lund University \\ Box 170, S-221 00, Sweden
}

ABSTRACT / Do altered land management practices offer possibilities to sequester carbon in the soil and thereby mitigate increasing atmospheric $\mathrm{CO}_{2}$ as well as improve local soil fertility? This study investigates the impact of fallow periods on soil organic carbon in semiarid subsistence agroecosystems on sandy and poor soils in Kordofan, Sudan. The area is characterized by low-input cultivation of millet and sorghum in combination with livestock grazing. Recently, cultivation intensity has increased and the fallow periods have been short- ened. Soil carbon contents were assessed for sites that have been under various cultivation intensities, ranging from 30 years of fallow to 30 years of continuous cultivation. Soil organic carbon showed a significant negative relationship with cultivation intensity. Measurements indicate a mean increase of approximately $4 \mathrm{~g}$ soil organic carbon (SOC) per square meter per year during fallow periods. The possibilities of increasing soil organic carbon by land management were also estimated through simulations using the Century model. Modeling suggested that reverting an intensely cropped millet site to permanent grassland would sequester approximately 1-2 g $\mathrm{sOC} / \mathrm{m}^{2} / \mathrm{yr}$, with higher rates during the early part of the period. Continuous intense cultivation could decrease the currently low soil carbon levels even further. These results indicate that altered land management could contribute to transforming degraded semiarid agroecosystems from a source to a weak sink for atmospheric $\mathrm{CO}_{2}$. Possible data improvements and uncertainties are discussed.
Consensus has now been reached by both the scientific and political communities that atmospheric $\mathrm{CO}_{2}$ concentrations are increasing and thus threatening to play havoc with the global climate system, as stated by the Intergovernmental Panel on Climate Change (IPCC 2001) and in the UN Framework Convention on Climate Change (Macilwain 2000).

The Kyoto Protocol (1997) negotiated a framework for reducing the emissions of greenhouse gases in December 1997. The protocol also recognized that some terrestrial ecosystems have the potential to sequester large amounts of carbon (C) and thus further slow down the increase of atmospheric $\mathrm{CO}_{2}$ concentrations. An increase of the soil organic matter (SOM) and the biomass pools could buy time while reducing fossil fuel related emissions of $\mathrm{CO}_{2}$. $\mathrm{SOM}$ is assumed to contain $50 \%$ C (SOC, soil organic carbon).

Land use changes that degrade terrestrial resources will continue to be a dominant driver of environmental

KEY WORDS: Carbon sequestration; Sudan; Agriculture; Fallow; Modeling

Published online December 23, 2003.

*Author to whom correspondence should be addressed, email: jonas.ardo@nateko.lu.se change in semiarid areas for future decades (Scholes and van Breemen 1997). These degraded semiarid areas have a large potential to sequester carbon in the soil, which is preferred to storage in above-ground vegetation due to longer residence times (Lal and others 1999). Batjes (1999) estimated that between 0.6 and $2 \mathrm{Pg} \mathrm{C} / \mathrm{yr}$ could be sequestered by the large-scale application of appropriate land management in the world's degraded lands. This accounts for $18-60 \%$ of the annual increase of $\mathrm{CO}_{2}$ in the atmosphere. Squires (1998) estimated the attainable sink in dry lands to be $1.0 \mathrm{Pg} \mathrm{C} / \mathrm{yr}$ over the next 50 years. Desertification control could globally sequester $0.9-1.9$ $\mathrm{Pg} \mathrm{C} / \mathrm{yr}$ for 25-50 years (Lal 2001). In addition to the removal of atmospheric $\mathrm{CO}_{2}$, increasing SOM in semiarid environments is socioeconomically appropriate (Tschakert 2001) and beneficial for food production and erosion control, often in poor and degraded areas.

This paper assesses the effects of continuous cultivation and fallow periods in low input subsistence agriculture on SOC in the semiarid Sudan. We would like to understand if extended fallow periods are a feasible management option for increasing soil carbon sequestration in degraded semiarid ecosystems while simultaneously improving soil quality.

This investigation is based on soil samples from the 1960s as well as recent soil samples. Measured and 
modeled examples relating the length of the fallow periods to SOC are included. The specific aim is to investigate the effects of cultivation intensity on SOC and in the semiarid Sudan through: (1) quantifying and comparing measured SOC for areas with varying cultivation intensities; and (2) estimating current and future SOC by using a biogeochemical model in order to quantify the attainable SOC change due to different cultivation intensity. Our hypothesis is: $\mathrm{h}_{0:}$ SOC in areas with low cultivation intensity $=$ SOC in areas with high cultivation intensity, and $h_{1}$ SOC in areas with low cultivation intensity $\neq$ SOC in areas with high cultivation intensity.

\section{Background}

Traditional, nonmechanized, rain-fed agriculture, without the use of any type fertilizers or addition of organic matter, is common in central and western Sudan (Craig 1991). The use of fallow periods is the only measure taken to improve soil fertility in the area. In Northern Kordofan Province, land is conventionally cultivated for 4-6 years and then left fallow for 15-20 years. During the last few decades, the length of the fallow periods has been reduced (Jewitt and Manton 1954, Davies 1985, Craig 1991, Khogali 1991, Olsson and Rapp 1991). This reduction may be caused by an increased demand for food; reduced crop yield (Olsson 1993) due to decreasing precipitation, soil degradation, crop diseases, and parasites (Khogali 1991); and an increased desire to grow cash crops (e.g., ground nuts).

\section{Fallow Periods}

Conversion of native land to cultivated land generally decreases SOM (Cole and others 1989, Scholes and van Breemen 1997, DOE 1999, Schlesinger and Andrews 2000). During intense cultivation without fertilization or the addition of organic matter, this decrease may occur rapidly (Buyanovsky and Wagner 1998).

When continuous millet cultivation, as in Kordofan, is combined with annual burning prior to planting and the removal of most crop residues after harvest, we might expect a decrease of SOM and N. Continuous millet cultivation on sandy soils in Burkina Faso has been reported to slowly deplete soil N and P (Krogh 1997). In Niger, significant increases of $\mathrm{C}$ and $\mathrm{N}$ with fallow age on sandy soils $(<4.5 \%$ clay) were found (Wezel and Boecker 1998). During the fallow periods, SOM increased and the natural regeneration of Acacia senegal and other Acacia species was common.

Acacia senegal, a nitrogen-fixing species, is important in reclaiming degraded lands in the tropics through improvement of soil properties (Alstad 1991, Njiti and
Galiana 1996). Jewitt and Manton (1954) compared an exhausted site, which had been continuously cultivated for 30 years, with an area taken out of cultivation and allowed to regenerate as a gum forest (Acacia senegal). Organic $\mathrm{N}$, exchangeable calcium, and $\mathrm{pH}$ were much higher in the gum forest. The $\mathrm{N}$ content of the upper $15 \mathrm{~cm}$ was $190 \mathrm{ppm}$ in the gum forest and $90 \mathrm{ppm}$ in the exhausted site. After clearing of the gum forest, the two sites were cultivated with sesame (Seasamum orientale) and groundnuts (Arachis hypogae). The sesame yield was five times higher and the groundnut yield one and a half times higher from the cleared forest compared with the harvest from the exhausted site. The exhausted site also showed a strong response to chemical fertilizers. The study was undertaken on the sandy soils (arenosol) in Umm Ruwaba, approximately 125 $\mathrm{km}$ SE of Bara, Sudan, which is close to our study site and with similar conditions. No SOC data were presented in the study, but it is probable that the gum forest site had a higher SOC content then the exhausted site.

Annual average crop yields (production) are generally lower for cropping systems with longer fallows compared to more intense cultivation in environments like the one studied here. Productivity (yield per year and per area unit) is often higher for cropping systems with longer fallows compared to more intense cultivation (short or no fallows). Provided that farmers have enough land to maintain long fallows, they may also maintain high productivity.

Additional environmental benefits of fallow periods with trees include lower soil temperatures, higher soil moisture, higher SOC (Abril and Bucher 2001), greater fuel production, and the possibilities of tapping gum (Haaland 1991, Khogali 1991) and shade for grazing animals. Litter produced by woody plants is beneficial due to its higher content of polyphenols (lignins and tannins) in the litter, which decreases the decomposition rate (Abril and Bucher 2001), when compared to grasses and annual herbs.

\section{Soil Quality Improvement by SOM}

SOM has favorable effects on the chemical, physical, and thermal properties of the soil, as well as on its biological activity. Soil quality is improved by an increased SOM content through better water-holding capacity, improved microaggregate structure, preventing erosion, and providing a stabilizing effect on the soil structure (Jewitt and Manton 1954, Gerakis and Tsangarakis 1970, Batjes and Sombroek 1997, Batjes 1999, Lal and others 1999). It is also an important determinant of the cation exchange capacity of soils (Batjes 1999). There is also commonly a clear correlation be- 


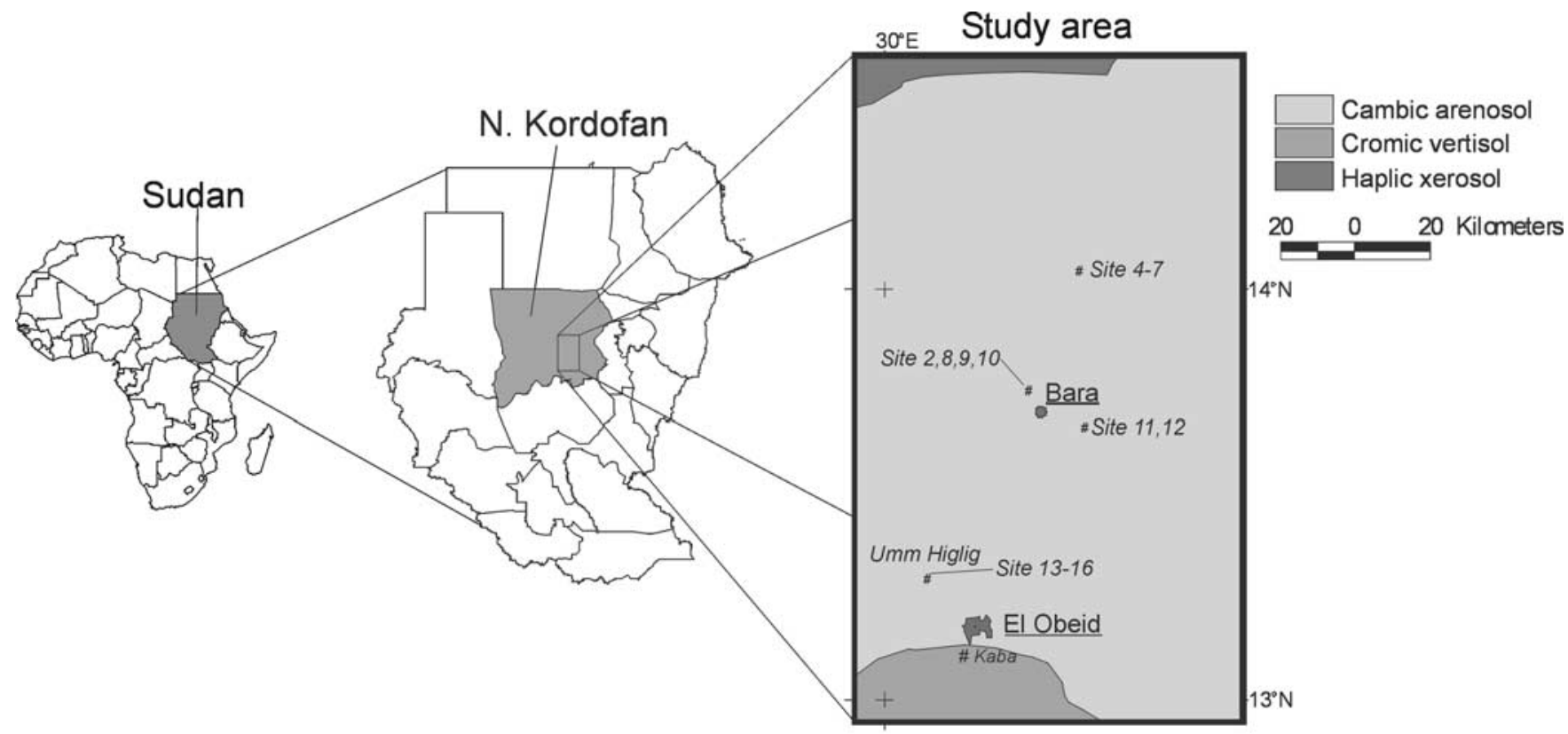

Figure 1. Study area including and the soil sampling sites the experimental sites (Kaba and Umm Higlig).

tween SOC in the topsoil and crop yields (Sombroek and others 1993). Large pools of SOM with low decomposition rates also permit a slow mineralization of $\mathrm{N}$ and other nutrients. The favorable effects of SOM vary with soil type, crops and farming system (Lal and others 1998).

\section{Reasons for Soil Carbon Sequestration}

There are several reasons for the encouragement of soil carbon sequestration in degraded semiarid areas, especially if the hidden carbon costs connected to fertilizer production, irrigation, etc. (Schlesinger 2000), could be minimized or avoided. The improvements of soil quality and soil properties caused by an increase of SOM (Batjes and Sombroek 1997, Lal 2001, 2002) (see above) counteract soil degradation (Martius and others 2001) and could contribute to food production via increased soil fertility (Sanchez 2002). Increased SOM also constitutes a carbon sink that could be traded (McDowell 2002, Natsource 2002, Olsson and Ardö 2002).

For the semiarid Sudan, the use of extended fallow periods with Acacia senegal may be a management alternative, in combination with others, for carbon sequestration that has small hidden costs and that benefits environmental quality and soil properties. An income from carbon trading could compensate for a decrease in agricultural production and income caused by re- duced cultivated areas and reduced grazing (Olsson and Ardö 2002).

\section{Data and Methodology}

The description of the study area is followed by a description of the measurements and modeling performed. Soil samples were collected at two sites for quantification of SOC changes over time and at 14 sites for comparing SOC and cultivation intensity.

Modeling was performed for two sites to describe SOC changes over time and modeling for validation was performed for 13 sites.

\section{Study Area}

This study was undertaken in the rural councils of Bara and El Obeid in the province of Northern Kordofan, Sudan (Figure 1).

Climate and vegetation. The climate is semiarid with annual rainfall ranging from less than $200 \mathrm{~mm}$ in the north to about $350 \mathrm{~mm}$ in the south. Almost all precipitation falls during the summer (May to October). Mean annual temperature in Bara is $27.5^{\circ} \mathrm{C}$ and the potential evaporation in El Obeid has been estimated to $2030 \mathrm{~mm} / \mathrm{yr}$ (Elagib and Mansell 2000). North of $14^{\circ} \mathrm{N}$ latitude, the area is a semidesert with sparse woody vegetation. South of $14^{\circ} \mathrm{N}$ latitude, the area is a mosaic of forest savanna and grassland. Common trees 
Table 1. Measured $^{a}$ soil data for experimental sites

\begin{tabular}{lll}
\hline & Umm Higlig & Kaba \\
\hline Texture: sand, silt, clay $(\%)$ & $94.2,0.9,4.9$ & $88.8,1.8,9.4$ \\
SOC, $0-20 \mathrm{~cm}\left(\right.$ mean $\left.\pm \sigma, \mathrm{g} / \mathrm{m}^{2}\right)$ & & $1008 \pm 257$ \\
$1963(N=16)$ & $851 \pm 256$ & $452 \pm 178$ \\
$2000(N=4)$ & $227 \pm 32.6$ & 556 \\
Difference $1963-2000\left(\mathrm{~g} \mathrm{C} / \mathrm{m}^{2}\right)$ & 16.8 & 15.0 \\
Mean annual change $\left(\mathrm{g} \mathrm{C} / \mathrm{m}^{2} / \mathrm{yr}\right)$ & \\
\hline
\end{tabular}

${ }^{a}$ All values representative for the upper $20 \mathrm{~cm}$ of the soil profile.

are Acacia spp., Balanites aegyptica, and broad-leafed species of the family Combretaceae. Acacia senegal is a characteristic tree where rainfall is $280-450 \mathrm{~mm} / \mathrm{yr}$ (Olsson and Rapp 1991). Common grasses are Aristida pallida, Eragrostis tremula, and Chenchrus bifolius.

Soil. The dominant soil types of the study area are Xerosols, Arenosols, and Vertisols (FAO-UNESCO 1977). The Haplic Xerosols in the northern part of the area are generally fine textured with clayey topsoil comparatively rich in organic matter in spite of the low rainfall. The Cambic Arenosols that cover the largest part of the area are coarse textured soils of aeolian origin, locally named $Q o z$ soils (Warren 1970). The texture is characterized by $60 \%-70 \%$ coarse sand, 20\%-30\% fine sand and 5\%-10\% clay (Mitchell 1991). A small part of the area in the south is covered by Chromic Vertisols, locally named Gardud, which are clay soils mixed with aeolian sand.

Cultivation, land use, and fallow. Land use intensity gradually increases with rainfall. In the north only extensive and partly migratory grazing by camels and goats is possible due to the lack of permanent water (Olsson 1985, Haaland 1991). The area around Bara is used for grazing and livestock breeding and a portion is cultivated. Cultivation is dominated mainly by millet (Pennisetum typhoideum) and to a lesser extent sesam (Sesamum indicum), watermelon (Citrullus vulgaris), karkadé (Hibiscus sabdariffa), and groundnuts (Arachis hypogaea), when rainfall and water resources increase to the south. Sorghum (Sorghum vulgare) replaces millet on the finely grained Vertisols in the south.

It is evident from interviews (Olsson and Ardö 2002) and the literature (Jewitt and Manton 1954, Davies 1985, Haaland 1991, Khogali 1991, Olsson and Rapp 1991) that land use practices have changed noticeably over the last three to four decades from a rotation system with long fallow periods (15-20 years) interspersed with short periods of cultivation ( $4-5$ years) to more or less continuous cultivation. During the same period, annual crop yields per unit area have decreased, mainly due to a marked decline of rainfall but to some extent also due to the shortening of fallow periods (Olsson 1993). Increased demand for food due to the population increase combined with decreasing yields have forced farmers to extend their cultivated area, primarily by reducing fallow periods.

\section{Experimental Sites}

In 1963, within a UN/FAO-supported project, two experimental sites, Kaba and Umm Higlig, were established outside El Obeid (DOXIADIS 1964) (Figure 1). The main purpose of the experiments was to study the effects of fertilizers, crop varieties, and soil management on crop production. The SOC changes from 1963 to 2000 for these two sites were calculated from soil samples collected in 1963 (DOXIADIS 1964) and in 2000 . The land use history of the two sites is not complete, but it is clear that the samples from 1963 represent undisturbed sites. This could provide information on the amount of SOC at undisturbed sites and the change over time could indicate the recoverable amount of SOC.

Umm Higlig. Umm Higlig $\left(13.2862^{\circ} \mathrm{N}, 30.0994^{\circ} \mathrm{E}\right)$ is located on an uniform Cambic Arenosol, approximately $18 \mathrm{~km}$ northwest of El Obeid (Figure 1, Table $1)$. The area is flat and, in 1963, the dominant tree specie was Acacia senegal. Grass (mainly Aristida sp., Cenchrus sp.) and herbs covered approximately $60 \%$. The soil is in deep sand with $94 \%$ sand, $2 \%$ silt, and $4 \%$ clay (Skerman 1966). This site was chosen as typical for the Qoz sand sheet soils. Prior to the establishment of the experiment, the site was fallow for 17 years. In May-June 1963, the site was cleared by hand and stumps and debris were removed (DOXIADIS 1964). The field trials followed after the clearing. There is no information on land use and land cover during the period 1966-1995.

The site was under fallow from 1996 to 2000 (Sayed Malik Abdel Raman, Range and Pasture Administration, personal communication) and in March 2000 was covered by scattered Acacia senegal and Usher (Calotropis procera).

Kaba. Kaba is located on a Chromic Vertisol (a clay soil mixed with aeolian sand) $7 \mathrm{~km}$ south of El Obeid 
Table 2. General data of the soil sampling sites ${ }^{a}$

\begin{tabular}{llll}
\hline Site & $\begin{array}{l}\text { Years of fallow }(-) \\
\text { or cultivation }^{\mathrm{b}}\end{array}$ & $\begin{array}{l}\text { Bulk density } \\
\left(\mathrm{g} / \mathrm{dm}^{3}\right)^{\mathrm{c}}\end{array}$ & $\begin{array}{l}\mathrm{C}\left(\mathrm{gm}^{2},\right. \\
0-20 \mathrm{~cm})\end{array}$ \\
\hline 2 & -5 & 1680 & 182.8 \\
3 & 1 & 1804 & 343.4 \\
4 & 30 & 1711 & 166.8 \\
6 & 3 & 1706 & 163.3 \\
7 & 7 & 1711 & 156.6 \\
8 & 2 & 1705 & 151.7 \\
9 & 10 & 1711 & 275.1 \\
10 & -17 & 1711 & 306.3 \\
11 & -20 & 1655 & 312.0 \\
12 & 20 & 1711 & 286.2 \\
13 & -4 & 1597 & 311.3 \\
14 & 10 & 1710 & 263.8 \\
15 & -30 & 1711 & 560.9 \\
16 & 2 & 1711 & 256.3 \\
\hline
\end{tabular}

asee Table 1 for Kaba and Umm Higlig.

${ }^{\mathrm{b}}$ Positive numbers denote years of cultivation, negative numbers denote years of fallow

${ }^{\mathrm{c}} \mathrm{A}$ mean value of $1711 \mathrm{~g} / \mathrm{dm}^{3}$ was used for sites without bulk density measurements.

$\left(13.1129^{\circ} \mathrm{N}, 30.1892^{\circ} \mathrm{E}\right)$ (Figure 1 , Table 1$)$. This experiment was also established in 1963. Prior to establishment, the site was under fallow for 15 years. According to the initial site description, the site was "reasonably representative of the peneplain soils common to the area south and south west of El Obeid" and classified as a "Acacia millifera pseudo savanna" (DOXIADIS 1964). In 1963 the vegetation was dominated by Acacia spp., especially Acacia nubica and Acacia millifera in the tree layer. Grass and herbs covered approximately $50 \%$ of the soil (DOXIADIS 1964).

The soil samples taken in 2000 were from a part of the experimental site that was not cultivated but kept under fallow during most of the experimental period.

\section{Soil Sampling and Analysis}

Soil sampling. In February-March 2000, soil samples were taken at 14 sites (Table 2), all located on the Qoz (i.e., the Arenosol described above) and at the two experimental sites described above. Samples were taken at 0 to $5 \mathrm{~cm}$ and at 15 to $20 \mathrm{~cm}$ depth with four subsamples at each site. All sites were located in the vicinities of Bara and El Obeid (Figure 1). Sample positions were determined with a global positioning system (GPS) receiver to an accuracy of $\pm 10 \mathrm{~m}$.

Soil analysis. Grain-size distribution was measured by sieving and sedimentation analysis. Due to the homogeneity of the soil in the region, soil texture was analyzed at three sites only $(2,6,13)$ on the Arenosol and one site (Kaba) located on the Vertisol. Bulk density was determined in the field through immediate weigh- ing of the samples collected with a core sampler. The samples were weighed without drying, as the area is very dry, and sampling took place in the spring, 4-5 months after the end of the rainy season (see also Poussart and others 2003b). SOC was analyzed with an elemental analyzer (Carlo Erba NA1500). For each site, mean SOC $\left(\mathrm{g} \mathrm{C} \mathrm{m}^{-2}, 0-20 \mathrm{~cm}\right)$ was calculated from the four subsamples at each level $(0-5 \mathrm{~cm}$ and $15-20 \mathrm{~cm})$. The average of these two mean values was used to describe the soil $\mathrm{C}$ content at 0 to $20 \mathrm{~cm}$ depth.

\section{Relationship of SOC to Cultivation Intensity.}

Each of the 14 sites was assigned a value describing the recent cultivation intensity (CI), consisting of a positive value describing the number of years with continuous cultivation or a negative value describing the length of the fallow periods in years. (i.e., a site that been under fallow for 25 years was assigned the value -25). This information was collected through detailed interviews with farmers. In order to investigate relationships, these values were regressed against the SOC for the sites. Variation in soil, soil texture, management, and crops are minimal for these 14 sites. Additionally, soil samples for the two experimental sites, collected in 1963 and 2000 were compared in order to reveal changes over time for these sites.

\section{Modeling SOC}

SOC was estimated using the Century model (Version 4.0) (Parton and others 1987, 1988, Metherell and others 1993). Century is an ecosystem model simulating biogeochemical fluxes of $\mathrm{C}, \mathrm{N}, \mathrm{P}$, and $\mathrm{S}$. The primary purpose of the model is as a tool for evaluating changes in climate and management of ecosystems. The model uses a monthly time step and estimates, among others, organic soil $\mathrm{C}$ and $\mathrm{N}$ for the upper $20 \mathrm{~cm}\left(\mathrm{~g} / \mathrm{m}^{2}\right)$ of the soil profile. The model has been widely used and validated (Burke and others 1989, Parton and others 1993, 1994, 1996, Bromberg and others 1996, Smith and others 1997, Ardö and Olsson 2003).

SOC was estimated for 10 cropland sites (sites 3, 4, 6, $7,9,10,13,14$, and 16 in Table 2 and the Kaba experimental site) and three undisturbed sites, located far away from villages and utilized for grazing only. For these sites, more detailed information was available. This information includes soil texture, bulk density, current crops, vegetation, and management information (land use history, soil cultivation, burning practices, crop residues, fallow periods, planting, weeding, harvest method, and harvest time) and was collected through field work and interviews in March 2000 (Olsson and Ardö 2002, Ardö and Olsson 2003). Additional information was collected from the literature 
(Jewitt and Manton 1954, DOXIADIS 1964, Davies 1985, Olsson 1985, Ahlcrona 1988, Craig 1991, Haaland 1991, Khogali 1991, Olsson and Rapp 1991). When estimating SOC for the selected sites, we tried to mimic the actual environment, management, and land use history as closely as possible using best available data. The initial SOC content required by the model was obtained by long-term model runs (Paustian and others 1996). Model validation was performed through comparing estimated and measured SOC for the 13 sites through linear regression.

Below are the current and future scenarios for the Kaba experimental station and for site 6 . These scenarios are based on best available data and reasonable estimates if data are missing. Site 6 is assumed to be representative of the sandy areas and the Kaba experimental site is assumed to be representative for the Chromic Vertisols south of El Obeid.

Kaba. The modeling executed for Kaba is based on the information below. Before the establishment of the experiment, the area was under fallow from 1948 to 1963 (DOXIADIS 1964). This fallow land was grazed annually from June to December. The site was cleared of trees and bushes in August 1963 but not cultivated, and the fallow continued until 1971. From 1972 to 1976 sorghum was cultivated and from 1977 to 1980 , the site was again under fallow. From 1981 to 2000, sorghum was continuously cultivated (Sayed Malik Adbel Raman, Range and Pasture Administration, El Obeid, personal communication). During cultivation, the fields were burned in May before hoeing and planting in June. Only hand soil cultivation (hoeing) took place with no fertilization or irrigation. The crop was harvested in October with approximately $85 \%$ of the straw removed. The remaining crop residues were grazed after the harvest during November and December.

Site 6. The modeling executed for site 6 is based on the information below. This site is a savanna woodland/ grassland with Acacia senegal and predominantly $\mathrm{C}_{4}$ grasses on a Cambic Arenosol in the central part of the area, $40 \mathrm{~km}$ north of Bara (Figure 1). The soil is of aeolian origin and coarse, consisting of $95 \%$ sand, $2 \%$ silt and 3\% clay with a bulk density of $1706 \mathrm{~g} / \mathrm{dm}^{3}$. Millet was cultivated on the site with an increasing crop-fallow ratio during the last century.

Before 1890 , the area was grazed annually with low intensity from July to October and a natural fire occurred every nineth year in February. During all cultivation periods, the land was burned in May before the planting in June. During the fallow periods there was a natural fire every nineth year as well. Crop-fallow ratios used in the model were 5:20 (1891-1915), 5:15 (19161935), and 5:10 (1936-1980). Acacia senegal invaded the fields during the fallow periods by natural regeneration. These trees were removed after each fallow period as cultivation began (Haaland 1991, Khogali 1991). From 1981 to 2000, the site was under a 3:3 rotation, i.e., three years of millet cultivation and then three years of fallow (information from interviews). There was no or very little tree regeneration during this period.

In general, the harvest occurs in October with $85 \%$ of the straw removed in addition to the grains. The remaining crop residues are grazed after the harvest during November and December. During fallow periods the area was grazed all year with low intensity.

Future Scenarios. To investigate the possibilities of increasing SOC over the period 2001-2100, the scenario described above for site 6 was extended using three hypothetical alternatives:

1 Conversion of the cultivated land to pasture with low intensity annual grazing from July to October.

2 Return to a rotation with millet cultivation for 5 years followed by 20 years of fallow. Acacia sengal invades during the fallow periods, and the site is grazed from June to December with low intensity.

3 Continuous millet cultivation.

Climate data. Climate data were available for three meterological stations: (1) Bara $\left(30.3^{\circ} \mathrm{E}, 13.7^{\circ} \mathrm{N}\right)$ with monthly precipitation data for 1908-1988, (2) El Obeid Aero $\left(30.2^{\circ} \mathrm{E}, 13.1^{\circ} \mathrm{N}\right)$ with monthly precipitation data for 1902-1994, and 3) El Obeid Town $\left(30.3^{\circ} \mathrm{E}, 13.1^{\circ} \mathrm{N}\right)$ with temperature data (monthly minimum and maximum) for the period 1943-1985. During model execution, precipitation data from Bara was used for site 6 and precipitation data from El Obeid Aero was used for the experimental site in Kaba. For the other sites, the closest stations were used. For all model simulations, temperature data from the El Obeid Town station were used. Missing data $(<10$ observations per station) within the observation periods were replaced with mean values of all observations available for the month with missing data. For model simulations outside the time span of actual observations long term mean values of all observations for each month were used.

\section{Results}

\section{SOC Measurements}

Long-term comparisons. In May 1963, the mean SOC content was $851 \mathrm{~g} / \mathrm{m}^{2}$ in Umm Higlig and $1008 \mathrm{~g} / \mathrm{m}^{2}$ in Kaba. In March 2000, the mean SOC content was 227 


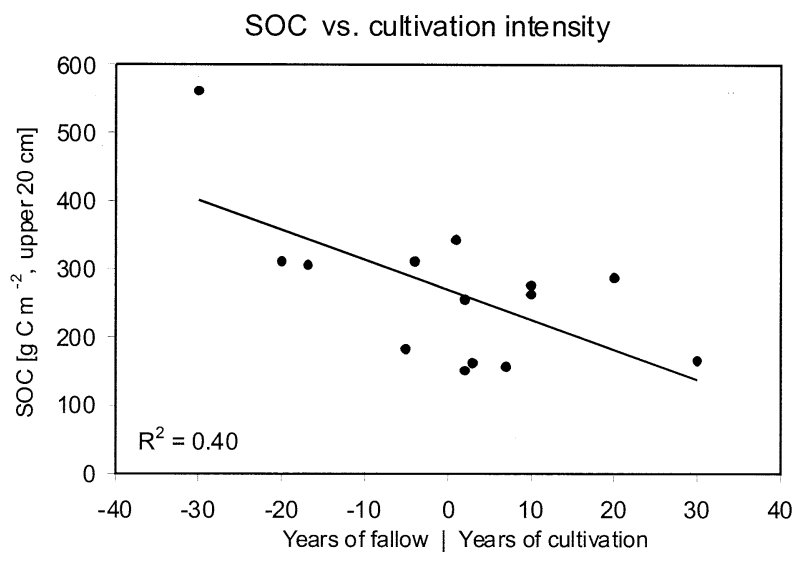

Figure 2. SOC measurements versus cultivation intensity. Negative numbers on the $x$ axis denote years of consecutive fallow and positive numbers consecutive years of cropping.

$\mathrm{g} / \mathrm{m}^{2}$ in Umm Higlig and $425 \mathrm{~g} / \mathrm{m}^{2}$ in Kaba. This is a decrease of $624 \mathrm{~g} \mathrm{C} / \mathrm{m}^{2}\left(16.8 \mathrm{~g} \mathrm{C} / \mathrm{m}^{2} / \mathrm{yr}\right)$ for $\mathrm{Umm}$ Higlig and $556 \mathrm{~g} \mathrm{C} / \mathrm{m}^{2}$ or $\left(15 \mathrm{~g} \mathrm{C} / \mathrm{m}^{2} / \mathrm{yr}\right)$ for Kaba (Table 1).

Cultivation intensity versus SOC. There is a significant $\left(r^{2}=0.40, P<0.02\right)$ negative relationship between cultivation intensity and SOC content in the upper 20 $\mathrm{cm}$ indicating increasing SOC during periods of fallow and a decreasing SOC during cultivation (Figure 2). The maximum SOC content $\left(560.9 \mathrm{~g} / \mathrm{m}^{2}\right)$ was collected at site 15 , which had been under fallow for 30 years. The minimum SOC of $151.7 \mathrm{~g} / \mathrm{m}^{2}$ was found at site 8 , which had been under fallow for 2 years. Site 4 , which had been continuously cultivated for 30 year had a SOC content of $166.8 \mathrm{~g} / \mathrm{m}^{2}$. The overall mean SOC content was $267 \mathrm{~g} \mathrm{C} / \mathrm{m}^{2}$. The regression (Figure 2) indicates a mean change of $\approx 4.3 \mathrm{~g} \mathrm{C} / \mathrm{m}^{2} / \mathrm{yr}$ as a function of fallow ( $\mathrm{C}$ increase) or continuous cultivation $(\mathrm{C}$ decrease) (a sequestration rate of $4.3 \mathrm{~g} \mathrm{C} / \mathrm{m}^{2} / \mathrm{yr}=$ $\left.0.043 \mathrm{t} \mathrm{C} / \mathrm{ha} / \mathrm{yr}=4.3 \mathrm{t} \mathrm{C} / \mathrm{km}^{2} / \mathrm{yr}\right)$.

\section{SOC Modeling}

Kaba. From 1948 to the early 1970s, SOC content was almost stable at a level slightly above $1000 \mathrm{~g} / \mathrm{m}^{2}$ (Figure 3). There was a decrease of $550 \mathrm{~g} \mathrm{C} / \mathrm{m}^{2}(\approx 20 \mathrm{~g}$ $\mathrm{C} / \mathrm{m}^{2} / \mathrm{yr}$ ) from 1972 to 2000 when the site was cultivated continuously, except for the period 1977-1980 (fallow) that corresponds with a slightly flatter part of the curve. Maximum SOC occurred in 1973, i.e., one year after the tree removal and burning that occurred in 1972 and prior to cultivation. The modeled SOC content corresponds reasonably with the measured SOC with a difference of $52 \mathrm{~g} / \mathrm{m}^{2}(\approx 5 \%)$ in 1963 and $93 \mathrm{~g} / \mathrm{m}^{2}(\approx 18 \%)$ in 2000 .
Site 6. From an equilibrium level of $390 \mathrm{~g} \mathrm{C} / \mathrm{m}^{2}$ in 1890 , the SOC content decreased gradually, as the cultivation became more intense from 1891 to 2000. In 2000 the SOC was $190 \mathrm{~g} \mathrm{C} / \mathrm{m}^{2}$ (Figure 4). This equals a mean annual decrease of $1.8 \mathrm{~g} \mathrm{C} / \mathrm{m}^{2}$. The rate of decrease that was faster during the first cultivation periods, thereafter stabilized (1950-2000). In the year 2000 , the estimated SOC was $28 \mathrm{~g} / \mathrm{m}^{2}$ higher (17\%) than the measured SOC.

Future scenarios. The estimated attainable SOC changes as a function of three hypothetical management scenarios during the next 100-year period are shown in Figure 4. A conversion from millet cultivation (3:3 rotation) to pasture increases the SOC by $127 \mathrm{~g} \mathrm{C} / \mathrm{m}^{2}$ during the 100 -year period. The sequestration is more rapid during the first $20-25$ years $\left(\approx 2 \mathrm{~g} \mathrm{C} / \mathrm{m}^{2} / \mathrm{yr}\right)$ and then declines progressively to $<1 \mathrm{~g} \mathrm{C} / \mathrm{m}^{2} / \mathrm{yr}$ when approaching 2100. The average $\mathrm{C}$ sequestration rate is $1.3 \mathrm{~g} / \mathrm{m}^{2} / \mathrm{yr}$.

Returning to a crop-fallow ratio of 5:20 slightly increases the SOC content from 190 in 2000 to 217 and $225 \mathrm{~g} \mathrm{C} / \mathrm{m}^{2}$ in 2050 and 2100 , respectively. The mean SOC for the period $2000-2050$ is $192 \mathrm{~g} \mathrm{C} / \mathrm{m}^{2}$, and for the period 2051-2100 the mean SOC is $211 \mathrm{~g} \mathrm{C} / \mathrm{m}^{2}$. The mean annual change is $0.3 \mathrm{~g} \mathrm{C} / \mathrm{m}^{2}$. The SOC dynamics as a function of the fallow/cultivation cycle is illustrated by the oscillations of the base scenario (Figure 4). There is a slow SOC increase during the fallow period and a faster SOC decrease during cultivation. The peaks correspond to the end of the fallow periods as the trees are cleared. This alternative does not yield any real soil $\mathrm{C}$ change over the next 100 years.

Continuous cultivation during the next 100 years will decrease the SOC by $98 \mathrm{~g} / \mathrm{m}^{2}$ (from 190 to $92 \mathrm{~g}$ $\mathrm{C} / \mathrm{m}^{2}$ ). During the first 20 years, SOC decreases with an average of $1.65 \mathrm{~g} \mathrm{C} / \mathrm{m}^{2} / \mathrm{yr}$. Over the full 100 -year period, the average decrease rate is $0.98 \mathrm{~g} \mathrm{C} / \mathrm{m}^{2} / \mathrm{yr}$.

Based on both the measurements and the modeling, the null hypothesis that states that SOC is not influenced by cultivation intensity, is rejected.

\section{Model Validation}

Comparing estimated and observed SOC yields, an $r^{2}$ of 0.70 and, 11 of 13 estimations are within $\pm 25 \%$ (Figure 5). The standard error of estimate is $62 \mathrm{~g} \mathrm{C} / \mathrm{m}^{2}$ and the mean absolute error is $49 \mathrm{~g} \mathrm{C} / \mathrm{m}^{2}$. The hypothesis that the regression coefficient is equal to zero is rejected at $99 \%$ level of significance.

\section{Discussion and Conclusion}

\section{soc Measurements}

There might be several reasons for the SOC decline at the experimental sites. For the Umm Higlig site, the 

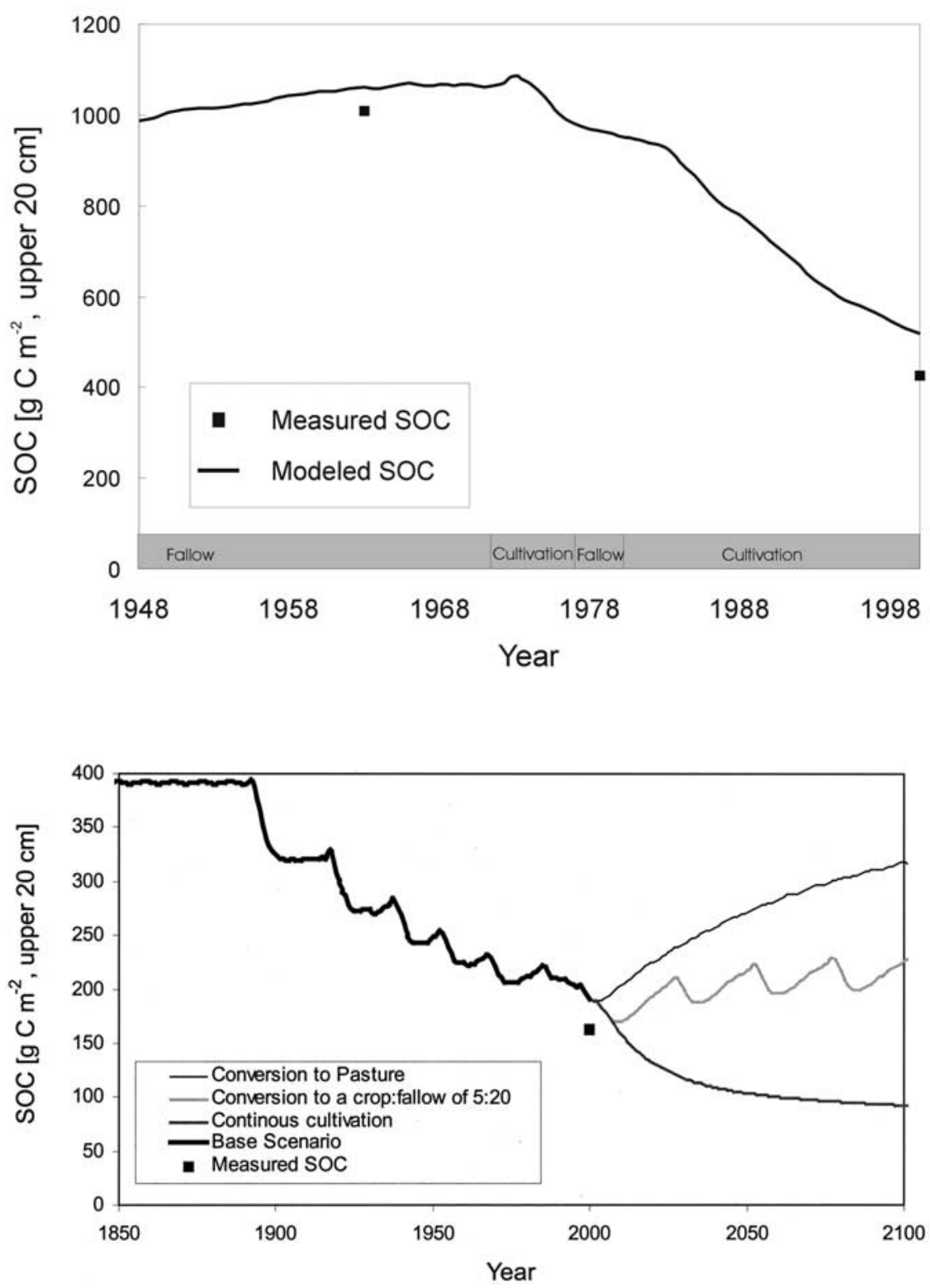

Figure 3. Modeled and measured SOC at the experimental site in Kaba.

Figure 4. Modeled and measured SOC at site 6 .

available information (DOXIADIS 1964) is not sufficient to identify any causes, although a comparison of old photos with our recent field visits indicates a decrease in vegetation cover, both for trees and grasses.

For the Kaba site, the long continuous cultivation of sorghum (1981-2000) has contributed to the rapid SOC decrease. The vegetation cover here was also less in 2000 than in 1963.

Both sites seem to have deteriorated in terms of vegetation cover, i.e., there is a decrease of organic $\mathrm{C}$ input to the soil. This may be caused by intense cultivation and grazing as well as a decrease in precipitation (Hulme and others 2001, Nicholson 2001). If this SOC decline is representative for the area in general, it indicates soil degradation. This form of degradation could also be viewed as potential carbon sink, partly available through management.

\section{SOC Estimation}

Kaba. The estimated SOC for the experimental site at Kaba (Figure 3) supports the assumption that SOC recovers during fallow periods and declines during periods of cultivation (as in the 1980- 2000 period). During the fallow period from 1977 to 1980, the SOC declined but at a lower rate compared to periods of cultivation. The acceptable fit with the measurements indicates that the model replicates the soil $\mathrm{C}$ dynamics of the Kaba site reasonably well. 


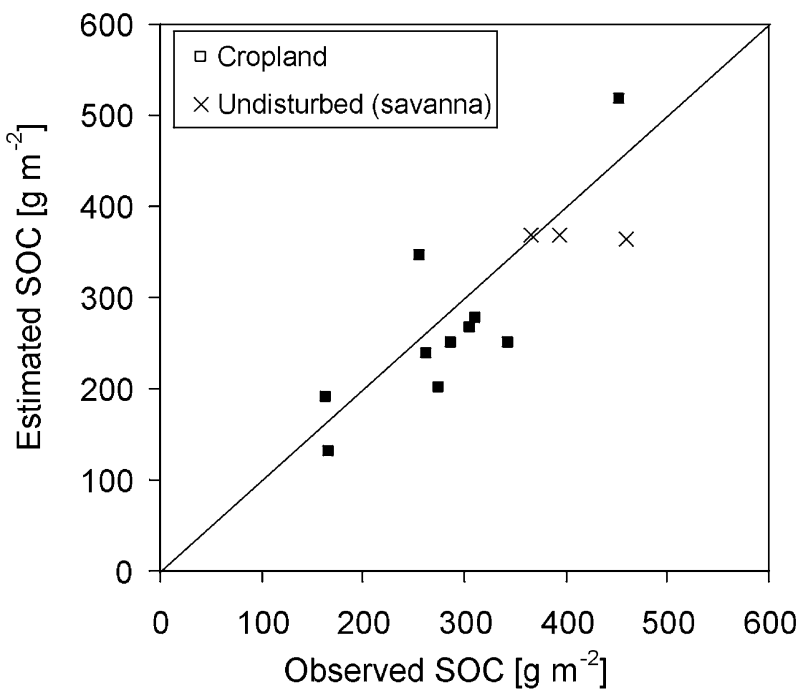

Figure 5. Model validation, observed SOC versus estimated SOC, $N=13, r^{2}=0.70$.

Site 6. The overall pattern of SOC change over time for site 6 (Figure 4) is similar to the pattern for Kaba (Figure 3), but the equilibrium level prior to cultivation is lower than at Kaba. This difference is probably due to the sandier soil and lower precipitation at site 6 . The dynamics caused by the increased cultivation intensity (increased crop:fallow ratio) is clear. SOC decreased steadily during the periods of continuous cultivation throughout the 20th century with small recovery periods during each fallow period.

The future SOC scenarios for a typical site in semiarid Kordofan show that changes of land use to pasture from cultivation increase the SOC. Continuous cultivation decreases SOC and soil fertility even further, with lower crop yields as a result. Returning to a crop-fallow ratio of 5:20 keeps the system in status quo, but still approximately $200 \mathrm{~g} \mathrm{C} / \mathrm{m}^{2}$ below the equilibrium level.

These results indicate that it is not only cultivation intensity that needs to be changed in order to increase SOC and soil fertility. Alternatives to the present practice of burning to remove pests prior to planting and the removal of crop residues during harvest could also influence SOC sequestration (Bird and others 2000, Tilman and others 2000, Poussart and others 2003a).

\section{Model Validation}

Despite the facts that reasonable correspondence between observed and estimated SOC (Figure 5) exist and that several evaluations of the Century model report good model performance (Burke and others 1989, Parton and others 1993, 1994, 1996, Bromberg and others 1996, Smith and others 1997, Mikhailova and others 2000), the estimation of historical, current, and future SOC over large areas is difficult.

First, available input data (soil texture, time series of precipitation and temperature, land management, grazing intensity, etc.) do not fully meet the model's demands. Uncertainties and errors in input data can strongly affect SOC estimates (Paustian and others 1997, 2003a). Large spatial and temporal variations in precipitation (Olsson 1985, Graef and Haigis 2001, Seaquist 2001) and spatial variations in soil properties make successful model execution over large areas challenging (Ardö and Olsson 2003).

Second, as CENTURY involves numerous parameters, model parameterization could be modified to better fit the local conditions. For example, reliable data on the magnitude of nitrogen fixation of Acacia senegal are hard to obtain.

Third, data on land use history are very important to the modeling because of the long residence time of some SOM pools. Reliable information about historical land-use, management, grazing, and fire patterns, etc., is hard to obtain and hence the land use history must always be simplified in the modeling. Data scarcity is particularly severe for applications in developing countries, but methods using the natural abundance of ${ }^{15} \mathrm{~N}$ and ${ }^{13} \mathrm{C}$ can offer additional information (Eshetu 2000).

Data uncertainty, parameter uncertainty, and model uncertainty cause uncertainties in both quantities and structure (Barkman 1998) that create uncertain model outputs. These uncertainties are difficult to quantify, but should be estimated and converted to probabilities (Ardö and others 2000), based on current studies (Poussart 2002).

Modeling versus measurements. The carbon sequestration rate derived from measurements of SOC in fields with various cultivation intensities $\left(4.3 \mathrm{~g} \mathrm{C} / \mathrm{m}^{2} / \mathrm{yr}\right.$; Figure 2) is about twice the modeled future sequestration rate $\left(\approx 2 \mathrm{~g} \mathrm{C} / \mathrm{m}^{2} / \mathrm{yr}\right.$; Figure 4 , future scenarios) when converting cropland to grazing. This discrepancy could be caused by incorrect data (both model input data and measurement data), an inaccurate model, or incorrect model parameterization. Studies of model sensitivity to variations in input data and parameter values (Paustian and others 1997, Poussart 2002, Poussart and others 2003a) could provide quantifications of uncertainties connected to predictions of SOC with the Century model. The measured loss of carbon (Table 1) is higher than the measured and modeled sequestration rates (Figure 2, Figure 4).

Verification. In order to verify that soil carbon sequestration has actually occurred, for example, over a commitment period of five or ten years, reliable and 
robust methods are needed. For example; in order to detect a change of 20 and $40 \mathrm{~g} \mathrm{C} / \mathrm{m}^{2}$, respectively, 29 and 8 soil composite samples are required given a known sample variance of 13,000 and assuming a normal distribution, (Poussart and others 2003b). This also assumes that each sample in the field is a composite of four subsamples that are to be thoroughly mixed in the field prior to analysis (Garten and Wullschleger 1999).

\section{Conclusion}

Based on measured SOC from old experimental sites, measured SOC from 14 sites with varying cultivation intensity, and model simulations, the null hypothesis was rejected. It is concluded that agricultural management influences the rate of soil carbon sequestration on sandy soils in the semiarid Sudan. The attainable SOC increase, available through management, is low (1-4 $\left.\mathrm{g} \mathrm{C} / \mathrm{m}^{2} / \mathrm{yr}\right)$ per unit area but large areas are available.

Both the measurements and the modeling efforts should be complemented with further work on model sensitivity, model uncertainty and error propagation (Ardö and others 2000). Long-term agricultural experiments (Rasmussen and others 1998) and $\mathrm{CO}_{2}$ flux measurements (Verhoef and others 1996) should be established in the Sahel region in order to provide more detailed information on ecosystem processes and management effects.

\section{Acknowledgements}

We are grateful to the Sudanese personnel in the project: "Community Based Range Lands Rehabilitation for Carbon Sequestration and Biodiversity" (SUD/ 93/G31, SUD/96/017) for help provided during the fieldwork. Colorado State University is acknowledged for providing the Century model. The Swedish Science Council (contract 621-2001-1806) and the Crafoord Foundation (Ref. no. 000782) provided economic support for this study. The constructive suggestions from the reviewers are gratefully acknowledged.

\section{References}

Abril, A., and E. H. Bucher. 2001. Overgrazing and soil carbon dynamics in the western Chaco of Argentina. Applied Soil Ecology 16:243-249.

Ahlcrona, E. 1988. The impact of climate and man on land transformation in central Sudan. Lund, PhD-thesis, Lund University Press, 140 pp.

Alstad, G. 1991. The influence of Acacia tortilis on soil in arid north-eastern Sudan. University of Bergen, Bergen, Norway, 79 pp.
Ardö, J., and L. Olsson. 2003. Assessment of soil organic carbon in semi-arid Sudan using GIS and the Century model. Journal of Arid Environments 54:633-651.

Ardö, J., A. Barkman, and P. Arvidsson. 2000. Critical levels of $\mathrm{SO}_{2}$ in northern Czech Republic - uncertainties and relationship to regional forest decline. Geographical and Environmental Modelling 4:131-161.

Barkman, A. 1998. Critical loads - assessment of uncertainty. Lund, Ph.D.-thesis, Lund University, 47 pp.

Batjes, N. H. 1999. Management options for reducing $\mathrm{CO}_{2^{-}}$ concentrations in the atmosphere by increasing carbon sequestration in the soil. Dutch National Research Programme on Global Air Pollution and Climate Change \& Technical Paper 30 410-200-031, International Soil Reference and Information Centre, Wageningen, The Netherlands, 114 pp.

Batjes, N. H., and W. G. Sombroek. 1997. Possibilities for carbon sequestration in tropical and subtropical soils. Global Change Biology 3:161-173.

Bird, M. I., E. M. Veendal, C. Moyo, J. Lloyd, and P. Frost. 2000. Effect of fire and soil texture in a sub-humid savanna (Matopos, Zimbabwe). Geoderma 94:71-90.

Bromberg, J. G., R. McKeown, L. Knapp, T. G. F. Kittel, D. S. Ojima, and D. S. Schimel. 1996. Integrating GIS and the CENTURY model to manage and analyze data. GIS and Environmental Modeling: Progress and Research Issues 00:429-431

Burke, I. C., C. M. Yonker, W. J. Parton, C. V. Cole, K. Flach, and D. S. Schimel. 1989. Texture, climate, and cultivation effects on soil organic matter context in US grassland soils. Soil Science Society of America Journal 53:800-805.

Buyanovsky, G. A., and G. H. Wagner. 1998. Carbon cycling in cultivated land and its global significance. Global Change Biology 4:131-141.

Cole, C. V., J. W. B. Stewart, D. S. Ojima, W. J. Parton, and D. S. Schimel. 1989. Modelling land use effects of soil organic matter dynamics in the North American Great Plains. Pages Pages 89-98 in M. Clarholm, and L. Bergström. Eds, Ecology of arable land. Kluwer Academic Publishers, Amsterdam, Netherlands.

Craig, G. M., (ed.). 1991. The Agriculture of the Sudan. Oxford, Oxford University Press, 480 pp.

Davies, H. R. J. (ed.). 1985. Natural resources and rural development in arid lands: case studies from Sudan. United Nations University Press, Tokyo, 84 pp.

DOE. 1999. Carbon sequestration, state of the science. Working paper (draft, February 1999) US Department of Energy, Office of Science, Office of Fossil Energy, Washington, DC, 150 pp.

DOXIADIS. 1964. Land and water use survey in Kordofan province of the Republic of the Sudan. DOX-SUD-A25, Doxiadis Associates, Athens, Greece, 232 pp.

Elagib, N. A., and M. G. Mansell. 2000. Recent trends and anomalies in mean seasonal and annual temperatures over Sudan. Journal of Arid Environments 45:263-288.

Eshetu, Z., and P. Högberg. 2000. Effects of land use on ${ }^{15} \mathrm{~N}$ natural abundance of soils in Ethiopian highlands. Plant and Soil 222:109-117. 
FAO-UNESCO 1977. Soil map of the world, Volume VI, Africa. UNESCO, Paris, 299 pp.

Garten, C. T., and S. D. Wullschleger. 1999. Soil carbon inventories under a bioenergy crop (swithgrass): measurement limitations. Journal of Environmental Quality 28:1359-1365.

Gerakis, P. A., and C. Z. Tsangarakis. 1970. The influence of Acacia senegal on the fertility of a sand sheet (Goz) soil in the central Sudan. Plant and Soil 33:81-86.

Graef, F., and J. Haigis. 2001. Spatial and temporal rainfall variability in the Sahel and its effects on farmers' management strategies. Journal of Arid Environments 48:221-231.

Haaland, G. 1991. Production systems in Western Sudan. Pages 230-251 in G. M. Craig, (ed). The Agriculture of the Sudan. Oxford University Press, Oxford.

Hulme, M., R. Doherty, T. Ngara, M. New, and D. Lister. 2001. African climate change: 1900-2100. Climate Research 17:145-168.

IPCC. 2001. Summary for policymakers. IPCC WGI third assessment report. Intergovernmental Panel on Climate Change, $25 \mathrm{pp}$.

Jewitt, T. N., and J. S. Manton 1954. Soil exhaustion in the Goz sands of the Sudan. Pages 413-416 in Proceedings of Congrès international de la science du sol, Leopodville.

Khogali, M. M. 1991. Famine, desertification and vulnerable populations: the case of Umm Ruwaba District, Kordofan region, Sudan. Ambio 20:204-206.

Krogh, L. 1997. Field and village nutrient balances in millet cultivation in northern Burkina Faso: a village case study. Journal of Arid Environments 35:147-159.

Kyoto Protocol. 1997. Kyoto Protocol to the United Nations Framework Convention on Climate Change. FCCC/CP/ 1997/7/Add.1, Decision 1/CP.3, Annex, 7., UN, 39 pp.

Lal, R. 2001. Potential of desertification control to sequester carbon and mitigate the greenhouse effect. Climatic Change 51:35-72.

Lal, R. 2002. Carbon sequestration in dryland ecosystems of west Asia and north Africa. Land Degradation and Development $13: 45-59$.

Lal, R., J. M. Kimble, R. F. Follet, and B. A. Stewart, (eds). 1998. Soil processes and the carbon cycle. Boca Raton, CRC Press, 609 pp.

Lal, R., H. M. Hassan, and J. Dumanski. 1999. Desertification control to sequester $\mathrm{C}$ and mitigate the greenhouse effect. Pages 83-149 in Proceedings of St. Michaels workshop on carbon sequestration and desertification, Pacific Northwest National Lab., St. Michaels.

Macilwain, C. 2000. Congress wakes up to climate change. Nature 405:385.

Martius, C., H. Tiessen, and P. L. G. Vlek. 2001. The management of organic matter in tropical soils: what are the priorities?. Nutrient Cycling in Agroecosystem 61:1-6.

McDowell, N. 2002. Developing countries to gain from carbon-trading fund. Nature 420:4.

Metherell, A. K., L. A. Harding, C. V. Cole and W. J. Parton. 1993. Century soil organic matter model environment, technical documentation, agroecosystem version 4.0 . Technical Report No. 4, United States Department of Agricul- ture, Agricultural Research Service, Great Plains System Research Unit, $250 \mathrm{pp}$

Mikhailova, E. A., R. B. Bryant, S. D. DeGloria, C. J. Post, and I. I. Vassenev. 2000. Modeling soil organic matter dynamics after conversion of native grassland to long term continous fallow using the Century model. Ecological Modelling 132:247-257.

Mitchell, C. W. 1991. Physiography, geology and soils. Pages 1-18 in G. M. Craig, (ed). The Agriculture of the Sudan. Oxford University Press, Oxford.

Natsource. 2002. Assessment of private sector anticipatory response to greenhouse gas market development. Final analysis executive summary. Natsource, New York, 5 pp.

Nicholson, S. E. 2001. Climatic and environmental changes in Africa during the last two centuries. Climate Research 17:123-144.

Njiti, C. F., and A. Galiana. 1996. Symbiotic properties and Rhizobium requirements for effective nodulation of five tropical dry zone acacias. Agroforestry Systems 43:265-275.

Olsson, K. 1985. Remote sensing for fuelwood resources and land degradation studies in Kordofan, The Sudan. Lund, Ph.D.-thesis, Lund University, 182 pp.

Olsson, K., and A. Rapp. 1991. Dryland degradation in central Sudan and conservation for survival. Ambio 20:192-195.

Olsson, L. 1993. On the causes of famine-drought, desertification and market failure in the Sudan. Ambio 22:395-403.

Olsson, L., and J. Ardö. 2002. Soil carbon sequestration in degraded semiarid agro-ecosystems-perils and potentials. Ambio 31:471-477.

Parton, W. J., M. B. Coughenour, J. M. O. Scurlock, D. S. Ojima, T. G. Gilmanov, R. J. Scholes, D. S. Schimel, T. B. Kirchner, J.-C. Menaut, T. R. Seastedt, E. Garcia Moya, A. Kamnalruth, J. I. Kinyamario, and D. O. Hall. 1996. Global grassland ecosystem modelling: development and test of ecosystem models for grassland systems. Pages 229-279 in A. I. Breymeyer, D. O. Hall, J. M. Mellilio, and G. I. Ågren, (eds). Global Change: Effects on Coniferous Forests and Grasslands. John Wiley \& Sons, New York.

Parton, W. J., D. S. Ojima, and D. S. Schimel. 1994. Environmental change in grasslands: assessment using models. Climatic Change 28:111-114.

Parton, W. J., D. S. Schimel, C. V. Cole, and D. S. Ojima. 1987. Analysis of factors controlling soil organic levels of grasslands in the Great Plains. Soil Science Society of America Journal 51:1173-1179.

Parton, W. J., J. M. O. Scurlock, D. S. Ojima, T. G. Gilmanov, R. J. Scholes, D. S. Schimel, T. Kirchner, J. C. Menaut, T. Seastedt, E. Moya, G. A. Kamnalrut, and J. I. Kinyamario. 1993. Observations and modeling of biomass and soil organic matter dynamics for the grassland biome worldwide. Global Biogeochemical Cycles 7:785-809.

Parton, W. J., J. W. B. Stewart, and C. V. Cole. 1988. Dynamics of C, N, P and S in grasslands soils: a model. Biogeochemistry 5:109-131.

Paustian, K., E. T. Ellitot, G. A. Peterson, and K. Kendrick. 1996. Modelling climate, $\mathrm{CO}_{2}$ and management impacts on soil carbon in semi-arid agroecosystems. Plant and Soil 187:351-365. 
Paustian, K., E. Levine, W. M. Post, and I. M. Ryzhova. 1997. The use of models to integrate information and understanding of soil $\mathrm{C}$ at the regional scale. Geoderma 79:227-260

Poussart, J.-N. 2002. Verification of soil carbon sequestration uncertainties of assessment methods. Lund, MSc.-thesis, Lund University, 64 pp.

Poussart, J.-N., J. Ardö, and L. Olsson. 2004a. Effects of data uncertainties on estimated soil organic carbon in the Sudan. Environmental Management 33(Suppl 1):S405-S415.

Poussart, J.-N., J. Ardö, and L. Olsson. 2004b. Verification of soil carbon sequestration: sample requirements. Environmental Management 33(Suppl 1):S416-S425.

Rasmussen, P. E., K. W. T. Goulding, J. R. Brown, P. R. Grace, H. H. Janzen, and M. Körschens. 1998. Long term agrosystems experiments: assessing agricultural sustainability and global change. Science 282:893-896.

Sanchez, P. A. 2002. Soil fertility and hunger in Africa. Science 295:2019-2020.

Schlesinger, W. H. 2000. Carbon sequestration in soils: some cautions amidst optimism. Agriculture, Ecosystems $\mathcal{E}$ Environment 82:121-127.

Schlesinger, W. H., and J. A. Andrews. 2000. Soil respiration and the global carbon cycle. Biogeochemistry 48:7-20.

Scholes, R. J., and N. van Breemen. 1997. The effects of global change on tropical ecosystems. Geoderma 79:9-24.

Seaquist, J. S. 2001. Mapping primary production for the West African Sahel with satellite data. Lund, PhD-thesis, Lund University, 59 pp.

Skerman, P. J. 1966. Pastures and livestock in the Kordofan Special Fund Project area. DOX-SUD-A47, UN/FAO/DOXIADIS Associates, Athen, 150 pp.
Smith, P., J. U. Smith, D. S. Powlson, W. B. McGill, J. R. M Arah, O. G. Chertov, K. Coleman, U. Frankoe, S. Frolking, D. S. Jenkinson, L. S. Jensen, R. H. Kelly, H. Klein-Gunnewiek, A. S. Komarov, C. Li, J. A. E. Molina, T. Mueller, W. J. Parton, J. H. M. Thornley, and A. P. Whitmore. 1997. A comparison of the performance of nine soil organic matter models using datasets from seven long-term experiments. Geoderma 81:153-225.

Sombroek, W. G., F. O. Nachtergaele, and A. Hebel. 1993. Amounts, dynamics and sequestering of carbon in tropical and subtropical soils. Ambio 22:417-426.

Squires, V. R. 1998. Dryland soils: their potential as a sink for carbon and as an agent to mitigate climate change. Advances in GeoEcology 31:209-215.

Tilman, D., P. Reich, H. Phillips, M. Menton, A. Patel, E. Vos, D. Peterson, and J. Knops. 2000. Fire suppression and ecosystem carbon storage. Ecology 81:2680-2685.

Tschakert, P. 2001. Human dimenstions of carbon sequestration: A political ecology approach to soil fertility management and desertification control in the Old Peanut basin of Senegal. Arid Lands Newsletter 49.

Verhoef, A., S. Allen, H. A. R. De Bruin, C. M. J. Jacobs, and B. G. Heusinkveld. 1996. Fluxes of carbon dioxide and water vapour from a Sahelian savanna. Agricultural and Forest Meteorology 80:231-248.

Warren, A. 1970. Dune trends and their implications in the central Sudan. Zeitshrift für Geomorphologie Supplementband 10:154-180.

Wezel, A., and R. Boecker. 1998. Fallow plant communities and site characteristics in semiarid Niger, West Africa. Journal of Arid Environments 40:269-280. 